\title{
IMPLEMENTASI KOMPETENSI PEDAGOGIK GURU DALAM PEMBELAJARAN TEMATIK DI SEKOLAH DASAR
}

\author{
Yulyani, Tiara Kazumaretha, Yossa Arisanti, Yanti Fitria, Desyandri \\ Surel: yulyanipgsd17@gmail.com
}

\begin{abstract}
The objectives in this study are 1) to find out the implementation of pedagogical competence of teachers in thematic learning in SD Negeri 06 Kampung Lapai, 2) to find out the obstacles or problems experienced by teachers in implementing the pedagogical competence of teachers in thematic learning at SD Negeri 06 Kampung Lapai, 3) to find solutions to overcome obstacles in implementing teacher pedagogical competence in thematic learning at SD Negeri 06 Kampung Lapai. The method in this research is descriptive method with a qualitative approach. Data collection techniques used are observation, interviews, and also documentation. The results of the study that can be concluded are the implementation of teacher pedagogical competencies in thematic learning at SD Negeri 06 Kampung Lapai is already good, although there are some obstacles in applying it such as different teacher education backgrounds, weak methods and the use of instructional media. The efforts to overcome the problems that occur are by conducting functional training and teacher competence in the beginning of the new school year, and motivating teachers so that teachers can improve the learning process process for the better.
\end{abstract}

Keywords: Implementation, Pedagogical Competence,Thematic Learning.

\begin{abstract}
ABSTRAK
Adapun tujuan dalam penelitian ini yaitu 1) untuk mengetahui implementasi kompetensi pedagogik guru dalam pembelajaran tematik di SD Negeri 06 Kampung Lapai, 2) untuk mengetahui hambatan atau masalah yang dialami oleh guru dalam mengimplementasikan kompetensi pedagogik guru dalam pembelajaran tematik di SD Negeri 06 Kampung Lapai, 3) untuk mengetahui solusi mengatasi hambatan dalam pengimplementasian kompetensi pedagogik guru dalam pembelajaran tematik di SD Negeri 06 Kampung Lapai. Adapun metode dalam penelitian ini adalah metode deskriptif dengan pendekatan kualitatif. Teknik pengumpulan data yang digunakan yaitu observasi, wawancara, dan juga dokumentasi. Hasil penelitian yang dapat disimpulkan yaitu implementasi kompetensi pedagogik guru dalam pembelajaran tematik di SD Negeri 06 Kampung Lapai sudah baik, walaupun terdapat beberapa hambatan dalam menerapkannya seperti latar belakang pendidikan guru yang berbeda, lemahnya metode dan pengguaan media pembelajaran. Adapun upaya dalam mengatasi permasalahan yang terjadi yaitu dengan melakukan pelatihan fungsional dan kompetensi guru pada tahun awal ajaran baru, serta memotivasi guru agar guru dapat meningkatkan proses kegiatan pembelajaran menjadi lebih baik lagi.
\end{abstract}

Kata Kunci: Implementasi, Kompetensi Pedagogik, Pembelajaran Tematik 


\section{PENDAHULUAN}

Pendidikan di sekolah merupakan pengembangan potensi yang dimilki siswa, dengan ini seseorang akan menjadi manusia yang memilki keterampilan dalam menjalankan kehidupannya. Pendidikan tidak dapat dipisahkan dari kemajuan dan perkembangan bangsa. Kurikulum 2013 merupakan suatu usaha yang dilakukan oleh pemerintah dalam menciptakan masyarakat yang unggul baik dari segi ilmu maupun teknologi yang semakin berkembang. Dalam pengimplementasian Kurikulum 2013 ini diharapkan agar menjadi jembatan dalam mencapai tujuan yang diinginkan. Pelaksanaan pembelajaran di Kurikulum 2013 ini diarahkan menggunakan pendekatan pembelajaran tematik.

\section{Pembelajaran}

tematik

merupakan suatu pendekatan dalam proses kegiatan pembelajaran yang didalamnya terdapat beberapa Kompetensi Dasar (KD) dan indikator dari kurikulum/Standar Isi (SI) dari beberapa mata pelajaran menjadi satu kesatuan yang dikemas dalam bentuk tema (Sukayati dan Wulandari, 2009).

Menurut Peraturan Menteri Pendidikan Nasional Republik Indonesia Nomor 16 Tahun 2007 Tentang Standar Kualifikasi Akademik dan Kompetensi Guru, ada beberapa kompetensi yang harus dikuasai oleh guru seperti kompetensi pedagogik, kepribadian, profesional dan sosial yang diperoleh melalui pendidikan profesi. Dari berbagai kompetensi guru tersebut, salah satu kompetensi yang paling penting dimiliki oleh guru yakni kompetensi pedagogik karena dalam proses kegiatan pembelajaran guru sangat berperan penting dan juga kegiatan proses pembelajaran sebagai inti dari proses pendidikan secara keseluruhan yang melibatkan aspek kompetensi guru.

Di era sekarang ini, guru harus dapat mengembangkan ilmu pengetahuan dan wawasan yang dimilikinya dengan baik karena guru merupakan ujung tombak bagi pendidikan dalam mengembangkan peserta didik yang memiliki kemampuan, pengetahuan, dan keterampilan yang cukup. Artinya, jika seorang guru memiliki kemampuan dan kompetensi yang baik terutama dalam kegiatan proses pembelajaran maka peserta didik akan memiliki kemampuan, pengetahuan, dan keterampilan yang baik pula.

Berdasarkan dari hasil wawancara yang dilakukan oleh peneliti saat studi pendahuluan pada tanggal 05 dan 06 Februari 2020 dengan beberapa guru kelas yang menyatakan bahwa semua kelas di SD Negeri 06 Kampung Lapai telah menerapkan pembelajaran tematik sesuai dengan Kurikulum 2013. Namun, beberapa guru menyatakan bahwa guru mengalami kesulitan dalm mengimplementasikan pembelajaran tematik tersebut seperti dalam mengembangkan RPP, penerapan pedekatan saintifik, dan juga guru mengalami kesulitan dalam penilaian otentiknya. 

Untuk mendapatkan keberhasiln dalam mewujudkan pembelajaran tematik yang bermakna maka guru harus memiliki kompetensi terutama kompetensi pedagogik pada saat proses kegiatan pembelajaran. Kebermaknaan pada kegiatan pembelajaran tematik dapat dilakukan dengan menyajikan peserta didik dengan konteks kehidupan sehari-harinya. Berdasarkan hasil penelitian yang dilakukan oleh (Khofiatun, Akbar, \& Ramli, 2016) menyebutkan bahwa kompetensi pedagogik yang dimiliki oleh guru sangat berpengaruh terhadap proses kegiatan pembelajaran tematik yang dilaksanakan guru.

Selanjutnya penelitian yang dilakukan oleh (Purnamawati \& Kustiawan, 2018) yang menyebutkan bahwa dalam mengimplementasikan kompetensi pedagogik guru dalam pembelajaran tematik memiliki hambatan seperti guru lemah dalam penggunaan media, kurangnya sarana dan prasarana pada mata pelajaran tertentu, motivasi guru yang masih rendah, dan sebagainya.

Adapun tujuan dalam penelitian ini yaitu 1) untuk mengetahui implementasi kompetensi pedagogik guru dalam pembelajaran tematik di SD Negeri 06 Kampung Lapai, 2) untuk mengetahui hambatan atau masalah yang dialami oleh guru dalam mengimplementasikan kompetensi pedagogik guru dalam pembelajaran tematik di SD Negeri 06 Kampung Lapai, 3) untuk mengetahui solusi mengatasi hambatan dalam pengimplementasian kompetensi pedagogik guru dalam pembelajaran tematik di SD Negeri 06 Kampung Lapai.

\section{METODE PENELITIAN}

Penelitian ini menggunakan pendekatan kualitatif yang bertujuan untuk mendeskripsikan suatu masalah yang terjadi yang tidak bermaksud untuk menguji sebuah hipotesis tertentu. Adapun metode yang digunakan adalah metode deskriptif yaitu suatu penelitian dengan cara melakukan observasi, wawancara atau dengan menggunakan angket mengenai suatu permasalahan yang terjadi pada saat sedang melakukan sebuah penelitian, maupun mengenai subjek yang akan di teliti (Linarwati, Fathoni, \& Minarsih, 2016).

Dalam penelitian ini, peneliti berperan sebagai instrumen kunci ataupun sebagai pengumpul data penelitian. Penelitian ini menggunakan teknik sampling yaitu purposive sampling yaitu sampel yang digunakan sebagai sumber data dilakukan dengan adanya pertimbangan tertentu. Adapun sampel dalam penelitian ini yaitu SD Negeri 06 Kampung Lapai. Data dalam penelitian ini dikumpulkan dengan menggunakan observasi, dokumentasi, dan wawancara. Dalam penelitian ini menggunakan triangulasi dengan sumber dan teknik. Analisis data akan dilakukan setelah data secara keseluruhan telah terkumpul semua. 


\section{HASIL PENELITIAN DAN PEMBAHASAN}

Berdasarkan dari observasi dan hasil wawancara yang dilakukan, SD Negeri 06 Kampung Lapai telah menerapkan Kurikulum 2013 dengan pendekatan yang digunakan dalam kegiatan proses pembelajaran yaitu pembelajaran tematik. Adapun pembelajaran tematik tersebut di terapkan pada setiap kelas.

Adapun kompetensi yang dilihat di SD Negeri 06 Kampung Lapai pada kompetensi pedagogik yang meliputi sub kompetensi yaitu :

- Memahami karakteristik peserta didik secara mendalam

- Merancang sebuah pembelajaran dengan menguasai teori dan juga prinsip pembelajaran

- Melaksanakan

kegitan pembelajaran

- Merancang dan melakukan kegiatan evaluasi

- Mengembangkan potensi peserta didik

\section{Pembahasan}

Berdasarkan hasil penelitian yang dilakukan di SD Negeri 06 Lapai, maka peneliti memperoleh data bahwa di sekolah tersebut telah melaksanakan implementasi pedagogik dalam pembelajaran tematik dengan baik. hal itu di buktikan dengan kemampuan pedagogik guru dalam memahami karakteristik peserta didik seperti guru yang dapat mngidentifikasi karakteristik belajar setiap peserta didik, guru memantau peserta didik agar mendapatkan kesempatan yang sama dalam pembelajaran sehingga peserta didik menjadi aktif, serta guru dapat mengembangkan potensi peserta didik dan mengatasi permasalahan yang terjadi pada peserta didik.

Selain itu, kompetensi pedagogik dalam merancang sebuah pembelajaran juga telah baik, dimana semua guru telah menyususn silabus dan merancang RPP sesuai dengan pembelajaran tematik. Dalam melaksanakan kegiatan pembelajaran, hanya beberapa guru yang mengajar sesuai dengan RPP yang telah dibuat sebelumnya.

Adapun hambatan yang dialami oleh guru dalam mengimplementasikan kompetensi pedagogik dalam pembeljaran tematik seperti kurangnya sarana dan prasarana untuk mata pelajaran tertentu, pembelajaran masih berpusat pada guru, masih ada sebagaian guru yang usianya sudah tua sehingga mereka sudah jenuh dan malas melakukan inovasi dalam pembelajaran khususnya dalam penggunaan IT. Selain itu, ada beberapa guru yang lemah dalam menguasai media pembelajaran. Adapun solusi yang diterapkan di SD Negeri 06 Kampung Lapai yaitu dengan melakukan pelatihan fungsional dan kompetensi guru tiap tahunnya pada awal proses ajaran baru. Selain itu, kepala sekolah juga memberikan motivasi kepada guru agar lebi semnagat dalam mengajar. Upaya lain yang diterapkan di SD Negeri 06 Kampung Lapai dalam mengatasi permasalahan tersebut 
yaitu para guru saling mengingatkan dan juga mengajak kepada rekanrekan untuk saling membantu dan belajar menyesuaikan dengan perkembangan zaman seperti penggunaan IT.

\section{SIMPULAN}

Sesuai dengan hasil penelitian yang telah di bahas, maka peneliti membuat kesimpulan yaitu :

- Implementasi kompetensi pedagogik dalam pembelajaran tematik di SD Negeri 06 Kampung Lapai sudah baik. Hal tersebut dibuktikan dengan guru yang telah memahami karakteristik peserta didik secara mendalam, merancang sebuah pembelajaran dengan menguasai teori dan juga prinsip pembelajaran, melaksanakan kegitan pembelajaran, merancang dan melakukan kegiatan evaluasi, serta mengembangkan potensi peserta didik.

- Ada beberapa hambatan yang dialami oleh guru dalam pembelajaran tematik seperti kurangnya sarana dan prasarana, kurangnya pemahaman guru dalam penggunaan IT dan belum menguasai media yang sesuai dengan materi yang akan diajarkan.

- Solusi dalam mengatasi hal tersebut yang dilakukan di SD Negeri 06 Kampung Lapai yaitu dengan melaksanakan pelatihan pada awal tahun ajaran baru.
Selain itu, para guru terus menyesuaiakan dengan perkembangan zaman dengan cara mengingatkan dan belajar bersama dalam penggunaan IT dan media pembelajaran.

\section{DAFTAR RUJUKAN}

Khofiatun, Akbar, S., \& Ramli, M. 2016. Peran Kompetensi Pedagogik Guru dalam Pembelajaran Tematik di Sekolah Dasar. Jurnal Pendidikan, 1 (5), 984-988.

Linarwati, M., Fathoni, A., \& Minarsih, M. M. 2016. Studi Deskriptif Pelatihan dan Pengembangan Sumberdaya Manusia serta Penggunaan Metode Behavioral Event Interview dalam Merekrut Karyawan Baru di Bank Cabang Kudus. Journal of Management, 2 (2).

Purnamawati, W., \& Kustiawan, A. 2018. Implementasi Kompetensi Pedagogik dan Profesional Guru dalam Meningkatkan Prestasi Akademik Peserta Didik. Indonesian Journal of Education Management and Administration Review, 2(2).

Sukayati dan Wulandari, S. 2009. Pembelajaran Tematik Di SD. (A. Waluyati, Ed.). D.I. Yogyakarta: Departemen Pendidikan Nasional Direktorat Jenderal Peningkatan Mutu Pendidik dan Tenaga Kependidikan. 
